\title{
PENGARUH WAKTU FERMENTASI DAN KOMPOSISI LIMBAH KULIT BUAH AREN (Arenga pinnata) DENGAN STARTER KOTORAN SAPI TERHADAP BIOGAS YANG DIHASILKAN
}

\author{
Deril Clinton, Netti Herlina \\ Departemen Teknik Kimia, Fakultas Teknik, Universitas Sumatera Utara, \\ Jl. Almamater Kampus USU, Medan 20155, Indonesia \\ Email : deril_cp@yahoo.com
}

\begin{abstract}
Abstrak
Aren (Arenga pinnata) merupakan tanaman serbaguna. Pemanfaatanya yang luas dalam industri makanan menghasilkan limbah kulit buah yang dapat digunakan sebagai biomassa tanaman untuk pembuatan biogas. Penelitian ini bertujuan untuk mengetahui kualitas dan kuantitas biogas yang terbuat dari campuran limbah kulit buah aren dan air dengan menggunakan digester anaerobik sistem batch serta mengevaluasi potensi ekonomi dari biogas yang dihasilkan dari campuran tersebut. Penelitian dilakukan dengan mencampur kulit buah aren dengan air dalam rasio $1: 13 ; 1: 11,5 ; 1: 10 ; 1: 9 ;$ dan 1:8 (w/w) dengan starter kotoran sapi dicampur dengan air didalam digester anaerobik sistem batch. Variabel yang diamati adalah volume biogas, komposisi biogas, Total Suspended Solid (TSS) dan Chemical Oxygen Demand (COD) serta slurry dianalisis tiap 3 hari fermentasi. pH untuk penelitian ini diatur pada kisaran 6,4-8. Volume biogas terbesar pada rasio 1:11,5 (w/w) campuran limbah kulit buah aren dan yaitu $637 \mathrm{~mL}$ untuk total limbah sebanyak 1,5 L dengan kandungan metana sebesar $60.9830 \%$. Diperoleh persentase penyisihan TSS sebesar 88,10\% dan persentase penyisihan COD sebesar $82,43 \%$. Slurry menghasilkan TSS dan COD yang belum memenuhi baku mutu limbah cair. Potensi ekonomi dari pemanfaatan campuran limbah kulit buah aren dan air sebagai biogas menguntungkan.
\end{abstract}

Kata Kunci : biogas, COD, digester anaerobik, limbah kulit buah aren, TSS

\begin{abstract}
Sugar palm or commonly called as Aren (Arenga pinnata) is a multipurpose crop. The widely use of sugar palm for food industries, generates sugar palm leather waste which can be used as a biomass for biogas production. This study aims to determine the quality and the quantity of biogas made from a mixed of sugar palm leather waste and water using batch anaerobic digester system and to evaluate the economic potential of biogas production from the mixture. Research carried out by mixing sugar palm leather with water in a ratio of 1:13; $1: 11,5 ; 1: 10 ; 1: 9 ;$ and 1:8 (w/w) with cow dung as a starter mixed with water in an anaerobic digester batch system. Observed variables are biogas, biogas composition, Total Suspended Solid (TSS) and Chemical Oxygen Demand (COD) and analyzed fermentation slurry for every 3 days. $\mathrm{pH}$ for this study is set in the range of 6,4-8. The largest volume of biogas production is found at a ratio 1:11,5 (w/w) mixture of sugar palm leather and water that is $637 \mathrm{~mL}$ for total waste 1,5 L with 60,983\% methane contain. TSS removal percentage obtained was $88,10 \%$ and percentage of COD removal by $82,43 \%$. Slurry produces unqualified TSS and COD with the standard quality of liquid waste. The economic potential of sugar palm leather waste and water for producing biogas is beneficial.
\end{abstract}

Keywords : biogas, COD, anaerobic digester, sugar palm leather waste, TSS

\section{Pendahuluan}

Kondisi yang sedang terjadi saat ini, sumber energi minyak bumi semakin langka. Hal ini menjadi suatu permasalahan besar yang sedang dihadapi negara Indonesia [18]. Mengingat sumber energi minyak bumi Indonesia dari tahun ke tahun semakin menurun ini maka sudah selayaknya dilakukan segala upaya untuk mendapatkan energi alternatif [16]. Salah satu upaya untuk mengurangi ketergantungan terhadap bahan bakar fosil yang tidak terbarukan khususnya minyak dan gas bumi, yaitu dengan mensubstitusinya ke sumber energi baru dan terbarukan, khususnya bahan bakar nabati (biodiesel, bioetanol, biomassa dan biogas) [5]. Begitu pula pada pengunaan umpan biomassa untuk produksi biogas dengan pencernaan anaerobik. Dimana biogas dapat diproduksi dari residu padat maupun cair, begitu juga dengan biomassa tanaman [17].

Aren (Arenga pinnata) termasuk suku palempaleman yang memiliki berbagai fungsi antara lain fungsi konservasi dan fungsi ekonomis, sebab hampir semua bagian tanaman yaitu akar, batang, daun, dan buah dapat dimanfaatkan untuk berbagai keperluan manusia [8]. Dalam sekali panen jumlah buah yang dihasilkan berkisar antara 5-8 ribu per mayang dan rata-rata satu pohon aren mempunyai 7-9 mayang. Fungsi produksi aren dalam menghasilkan berbagai komoditi mempunyai nilai ekonomi tinggi dan berpotensi ekspor jika diusahakan secara serius, 
karena seluruh bagian tanaman dapat diolah menjadi berbagai produk pangan dan non pangan [13].

Ketersedian limbah kulit buah aren sebagai biomassa tanaman dan bahan organik yang cukup besar serta belum banyak pemanfaatannya memerlukan cara penanganan yang tepat. Oleh karena itu kulit buah aren tersebut dapat dimanfaatkan sebagai salah satu bahan baku pembuatan biogas.

\section{Teori}

Biogas adalah gas mudah terbakar yang diperoleh dari hasil dekomposisi senyawa organik oleh mikroorganisme secara anaerobik. Komponen terbesar yang terkandung dalam biogas adalah metana $55-70 \%$, karbon dioksida $30-45 \%$ serta sejumlah kecil, nitrogen dan hidrogen sulfida [2]. Secara umum, semua bahan organik dapat dijadikan bahan baku pembuatan biogas jika mengandung karbohidrat, protein, lemak, selulosa dan hemiselulosa sebagai komponen utama. Bahan baku juga harus terhindar dari bahan anorganik seperti pasir, batu, beling, dan plastik [3].

Sistem produksi biogas memiliki beberapa keuntungan, seperti mengeliminasi gas-gas rumah kaca, mengurangi bau, perbaikan pupuk, memproduksi panas dan energi. Biasanya, efisiensi pembuatan biogas bervariasi dengan kondisi operasi, tipe digester, dan jenis-jenis bahan atau materi yang ditambahkan ke dalam proses [6].

Proses pembentukan biogas terdiri atas empat tahapan utama yaitu hidrolisis, asidogenesis, asetogenesis, dan metanogenesis.

1. Hidrolisis

Hidrolisis secara teori merupakan tahap pertama dari fermentasi anaerobic, saat bahan-bahan organik komplek (polimer) didekomposisi menjadi unit-unit yang lebih kecil (mono- dan oligomer).

2. Asidogenesis

Asidogenesis ialah tahapan dimana produkproduk yang dihasilkan dari proses hidrolisis dikonversi oleh bakteri asidogenik menjadi substrat metanogenik.

3. Asetogenesis

Asetogenesis ialah tahapan dimana asam butirat dan dan propionat diuraikan oleh bakteri pembentuk asam menjadi asam asetat, gas $\mathrm{H}_{2}$, dan $\mathrm{CO}_{2}$.

4. Metanogenesis

Metanogenesis ialah tahapan paling akhir dimana bakteri metanogenik atau bakteri pembentuk metan menghasilkan gas metan, karbondioksida, dan sedikit gas lain [14].

Untuk mendapatkan produksi biogas yang optimum, perlu diperhatikan beberapa faktor dan kondisi yang dapat mempengaruhi perkembangan mikroorganisme di dalam fermentor. Beberapa faktor yang harus diperhatikan dan dijaga agar proses produksi biogas berjalan dengan stabil antara lain makro dan mikro nutrien, rasion $\mathrm{C} / \mathrm{N}$, temperatur, $\mathrm{pH}$, dan lama fermentasi.

\section{Metodologi Penelitian \\ Alat dan Bahan}

Bahan baku yang digunakan adalah limbah kulit buah aren dan air, sebagai bahan pembantu digunakan glukosa dan mikroorganisme yang berasal dari kotoran sapi yang di campur dengan air dengan perbandingan 1: 1 yaitu $25 \%$ dari volume digester terisi ( $2 \mathrm{~L})$. Alat utama yang digunakan ialah rangkaian alat digester anaerobik. Rangkaian peralatan yang digunakan dapat dilihat pada Gambar 1.

\section{Prosedur Percobaan}

Kulit buah aren di campur/diblender dengan air dalam rasio $1: 13 ; 1: 11,5 ; 1: 10 ; 1: 9$; dan 1:8 (w/w), kemudian ditambahkan glukosa dan starter (kotoran sapi) yang telah diaklimatisasi. Bahan isian dimasukkan ke dalam digester sebanyak $80 \%$ dari volume digester $(2,5 \mathrm{~L})$ yaitu sebanyak 2L. Tangki digester dihubungkan ke alat pengukur volume biogas, dimana volume gas diukur setiap tiga hari. Selanjutnya proses ditinjau hingga tercapai keadaan jumlah produksi gas menurun.

Pada tahap ini percobaan dilakukan pada digester anaerobik sistem batch. Dengan $\mathrm{pH}$ dijaga konstan antara 6,4-8, dan pada temperatur lingkungan $\left(25-30^{\circ} \mathrm{C}\right)$. Diamati paramaterparameter percobaan yaitu $\mathrm{pH}, \mathrm{COD}$ (Chemical Oxygen Demand), TSS (Total Suspended Solid), dan volume biogas, komposisi biogas, dan uji nayala biogas. Periode pengamatan dilakukan setiap 3 hari.

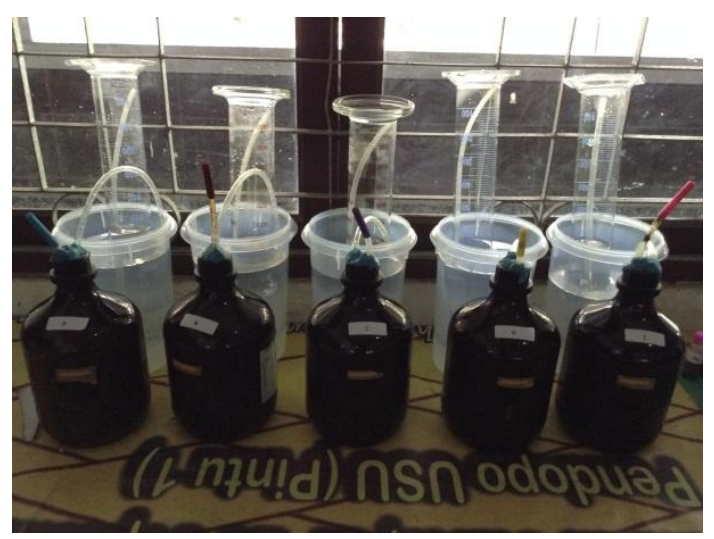

Gambar 1. Rangkaian Peralatan Pembuatan Biogas 


\section{Hasil Penelitian \\ Karakteristik Limbah Kulit Buah Aren}

Buah aren memiliki kelembaban $6,8 \%$, tersusun atas 7,9\% abu , 16,2\% serat kasar, $10 \%$ protein kasar dan 1,5\% lemak [11] dengan rasio $\mathrm{C} / \mathrm{N}$ 12. Adapun karakteristik limbah kulit buah aren dapat dilihat dari Tabel 1.

Tabel 1. Karakteristik Limbah Kulit Buah Aren

\begin{tabular}{|c|c|c|c|}
\hline $\begin{array}{c}\text { Komposisi } \\
\text { (Kulit Buah } \\
\text { Aren : Air) }\end{array}$ & pH & $\begin{array}{c}\text { TSS } \\
\text { (mg/L) }\end{array}$ & $\begin{array}{c}\text { COD } \\
\text { (mg/L) }\end{array}$ \\
\hline $1: 13$ & 7 & 1970 & 16200 \\
\hline $1: 11,5$ & 7 & 2100 & 14800 \\
\hline $1: 10$ & 7 & 2250 & 15200 \\
\hline $1: 9$ & 7 & 2410 & 17400 \\
\hline $1: 8$ & 7 & 2730 & 12500 \\
\hline
\end{tabular}

\section{Pengaruh Waktu Fermentasi Terhadap Derajat Keasaman (pH) Pada Beberapa Komposisi Sampel}

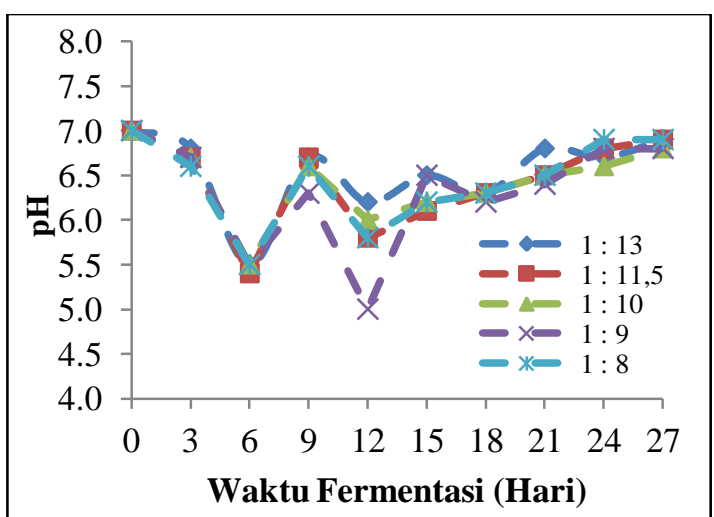

Gambar 2. Hubungan Waktu Fermentasi Terhadap Derajat Keasaman (Ph) Pada Beberapa Komposisi Sampel

Pada Gambar 2 dapat dilihat bahwa nilai derajat keasaman $(\mathrm{pH})$ mengalami fluktuasi terhadap waktu fermentasi untuk semua perbandingan komposisi sampel. Pada awal fermentasi sampai hari ke-3 pH berada pada kondisi netral dimana volume gas rata rata yang terbentuk yaitu sebesar 2,4 ml. Hal ini menunjukan pada tahap awal, proses hidrolisis lebih dominan di bandingkan proses asidogenesis, asetogenesis, dan metanogenesis. Menurut Seadi (2008), hidrolisis merupakan tahap awal pada fermentasi anaerobik dimana bahan organik komplek didekomposisi menjadi unit yang lebih sederhana [14].

Kemudian pada fermentasi hari ke-6 sampai hari ke- $15 \mathrm{pH}$ mengalami fluktuasi dengan $\mathrm{pH}$ terendah yaitu 5 dimana volume total gas rata rata sebesar 56,25 $\mathrm{ml}$. Terjadinya penurunan $\mathrm{pH}$ menunjukan fermentasi berada pada kondisi souring (pengasaman) akibat proses asidogenesis dan asetogenesis, dimana pada proses ini terbentuk asam-asam hasil konversi yang menyebabkan penurunan nilai $\mathrm{pH}$ dan mengakibatkan ketidakstabilan pada proses metanogenesis [9]. Dan pada fermentasi hari ke-18 sampai- ke-27 pH mengalami kenaikan menuju kondisi netral dengan volume total gas rata rata sebesar $100 \mathrm{ml}$. Pada tahapan ini proses produksi biogas mengalami kenaikan, hal ini menunjukan proses metanogenesis mengalami peningkatan dan berjalan secara efektif. Menurut Lettinga metanogenesis hanya akan berkembang dengan baik pada kondisi $\mathrm{pH}$ netral, dikarenakan bakteri metanogenik bekerja secara optimal pada kondisi $\mathrm{pH}$ netral [9]

\section{Pengaruh Waktu Fermentasi Terhadap \% Penyisihan TSS Pada Beberapa Komposisi Sampel}

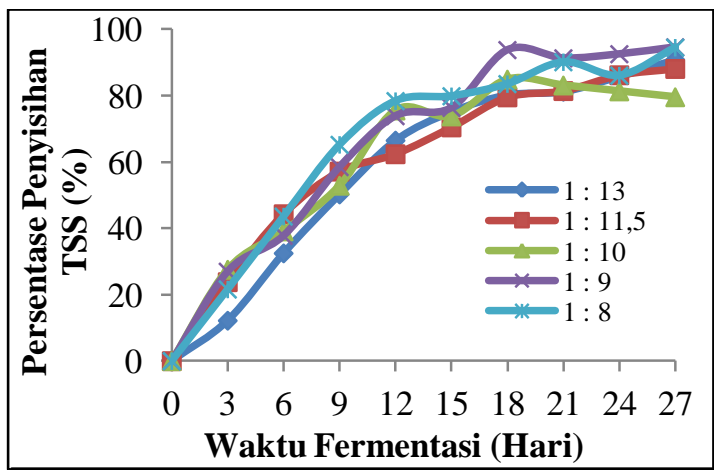

Gambar 3. Hubungan Waktu Fermentasi Terhadap \% Penyisihan TSS Pada Beberapa Komposisi Sampel

Pada gambar 3 dapat dilihat bahwa semakin lama waktu fermentasi maka persentase penyisihan total suspended solid (TSS) semakin meningkat. Menurunnya nilai TSS diakibatkan karena bahanbahan organik mengalami degadrasi pada saat proses pembentukan biogas. Dimana molekul kompleks yang ada dipecah menjadi molekul yang lebih kecil [4]. Namun setelah hari ke-18 pada beberapa komposisi nilai persentase penyisihan TSS cenderung stabil dan menurun disertai dengan menurunnya produksi biogas. Hal ini menunjukan untuk beberapa komposisi pada saat fermentasi mencapai tahap akhir zat padat organik tidak mampu lagi didegadrasi secara maksimal oleh bakteri akibat jumlah nutrisi pada bahan baku yang semakin berkurang [10].

Untuk perbandingan volume rasio limbah padat dan air 1:13 persentase penyisihan TSS terbesar yaitu 90,86\% pada hari ke-27 dengan nilai TSS $180 \mathrm{mg} / \mathrm{L}$, untuk perbandingan volume rasio limbah padat dan air 1:11,5 persentase penyisihan TSS terbesar yaitu $88,10 \%$ pada hari ke-27 dengan nilai TSS $250 \mathrm{mg} / \mathrm{L}$. Pada perbandingan volume rasio limbah padat dan air 1:10 persentase penyisihan TSS terbesar yaitu $84,89 \%$ pada hari ke-18 dengan nilai TSS $340 \mathrm{mg} / \mathrm{L}$, untuk perbandingan volume rasio limbah padat dan air 1:9 persentase penyisihan TSS terbesar yaitu $94,61 \%$ pada hari ke-27 dengan nilai TSS $130 \mathrm{mg} / \mathrm{L}$. Pada perbandingan volume rasio limbah padat dan air 1:8 persentase penyisihan TSS terbesar yaitu $94,51 \%$ pada hari ke-27 dengan nilai TSS $150 \mathrm{mg} / \mathrm{L}$. Untuk persentase penyisihan TSS terbesar pada semua variasi komposisi yaitu pada volume rasio limbah padat dan air 1:9 sebesar $94,61 \%$ pada hari ke-27 dengan nilai TSS $130 \mathrm{mg} / \mathrm{L}$. 


\section{Pengaruh Waktu Fermentasi Terhadap \% Penyisihan COD Pada Beberapa Komposisi Sampel}

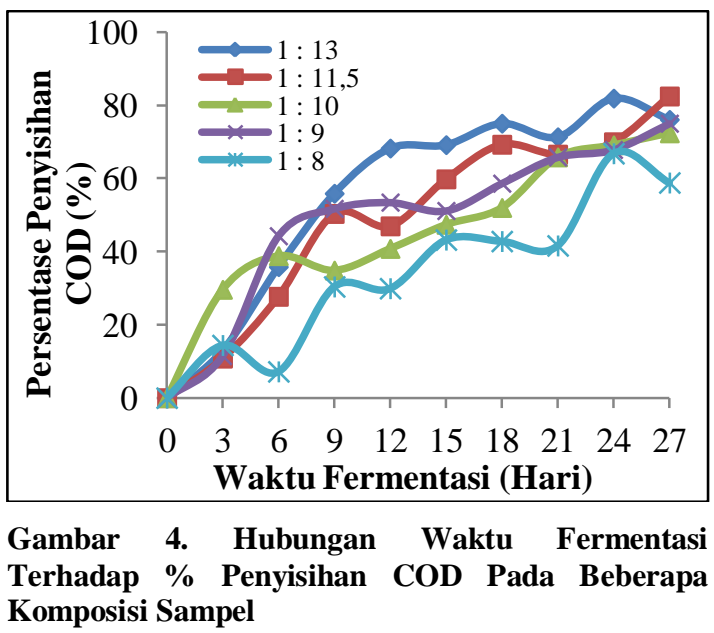

Pada gambar 4 dapat dilihat bahwa semakin lama waktu fermentasi maka \% penyisihan COD cenderung meningkat, tetapi pada waktu tertentu hasil analisa mengalami fluktuasi. Menurut Jorgensen (2009), semakin besar reduksi COD, berarti bahan organik yang terdegradasi menjadi asam-asam organik juga semakin besar. Asamasam organik inilah yang kemudian terkonversi menjadi biogas, maka jika reduksi COD semakin besar maka laju pembentukan biogas juga semakin besar [7]. Hal ini bertolak belakang dengan hasil yang didapat, yaitu pada beberapa komposisi persentase penyisihan COD terus meningkat setelah hari ke-18 dimana produksi biogas optimum. Dapat dikatakan pada saat produksi biogas optimum telah dicapai, bakteri tetap mampu mendegradasi senyawa organik meskipun volume biogas menurun. Menurut Azizah (2012), Penurunan kadar COD dalam hal ini dapat terjadi dengan terkonversinya senyawa organik menjadi gas $\mathrm{H}_{2}, \mathrm{CO}_{2}, \mathrm{NH}_{3}$ dan $\mathrm{CH}_{4}$ dan peningkatan waktu kontak dapat mengakibatkan biodegradasi organik berlangsung lebih lama sehingga kadar COD makin rendah [12].

Pada perbandingan volume limbah padat dan air 1:13 diperoleh persentase penyisihan COD terbesar pada hari ke-24 yaitu $81,85 \%$ dengan nilai COD $2940 \mathrm{mg} / \mathrm{L}$, kemudian persentase penyisihan COD menurun pada hari ke-27 dimana produksi biogas yang dihasilkan pun berkurang. Pada perbandingan volume limbah padat dan air 1:11,5 persentase penyisihan COD menurun pada hari ke-12 yang disertai penurunan nilai $\mathrm{pH}$ akibat akifitas bakteri asidongenesis dan asetogenesis serta diperoleh persentase penyisihan COD terbesar pada hari ke-27 yaitu 82,43\% dengan nilai COD $2600 \mathrm{mg} / \mathrm{L}$. Pada perbandingan volume limbah padat dan air 1:10 diperoleh penyisihan terbesar pada hari ke-27 yaitu $72,37 \%$ dengan nilai COD $4200 \quad \mathrm{mg} / \mathrm{L}$, $\quad$ Pada perbandingan volume limbah padat dan air 1:9 diperoleh persentase penyisihan COD terbesar pada hari ke-27 yaitu $75 \%$ dengan nilai COD 2940 4350mg/L, dan perbandingan volume limbah padat dan air 1:8 persentase penyisihan COD mengalami penurunan pada hari ke- 6 dan hari ke-12 yang disertai penurunan nilai $\mathrm{pH}$ akibat akifitas bakteri asidongenesis dan asetogenesis serta diperoleh persentase penyisihan COD terbesar pada hari ke-24 yaitu $66,80 \%$ dengan nilai COD $4150 \mathrm{mg} / \mathrm{L}$,. Untuk persentase penyisihan COD terbesar pada semua variasi komposisi yaitu pada volume rasio limbah padat dan air 1:11,5 sebesar $82,43 \%$ pada hari ke-27.

\section{Pengaruh Waktu Fermentasi Terhadap Volume Biogas Pada Beberapa Komposisi Sampel}

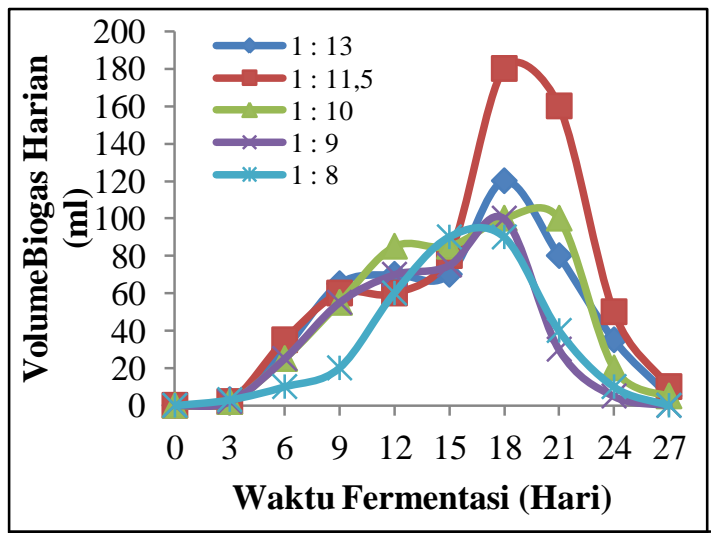

Gambar 5. Hubungan Waktu Fermentasi Terhadap Volume Biogas Pada Beberapa Komposisi Sampel

Pada Gambar 5 produksi biogas pada awal fermentasi cenderung rendah, kemudian produksi terus meningkat hingga pada hari ke-18 dimana produksi biogas mencapai titik optimum lalu menurun sampai gas tidak terbentuk lagi. Hal ini menunjukan bakteri metanogen bekerja secara efektif pada hari ke-18. Menurut fransiska (2011), pada awal proses fermentasi bakteri pembentuk biogas (metanogen) mengalami masa penyesuaian dengan keadaan di dalam bahan baku, kemudian mengalami pertumbuhan karena adanya pemanfaatan nutrisi hingga dihasilkan produksi biogas maksimal [1]. Pada tahap akhir, fermentasi memasuki fase stasioner dimana bakteri mulai kekurangan nutrisi dan mengalami kematian sehingga produksi biogas cenderung konstan dan mulai menurun [15].

Untuk semua perbandingan rasio antara limbah padat kulit buah aren dan air, biogas mulai dihasilkan pada hari ke-3 dan menghasilkan produksi biogas optimal pada hari ke-18. Total perolehan biogas untuk rasio antara limbah padat kulit buah aren dan air $1: 13 ; 1: 11,5 ; 1: 10 ; 1: 9$ 
dan 1:8 secara berturut-turut yaitu $478 \mathrm{ml}, 637 \mathrm{ml}$, $477 \mathrm{ml}, 362 \mathrm{ml}$, dan $323 \mathrm{ml}$. Dalam hal ini, perbandingan rasio antara limbah padat kulit buah aren dan air 1:11,5 dan menghasilkan volume biogas paling besar yaitu $637 \mathrm{ml}$.

\section{Komposisi Biogas}

Adapun tabel 2 di bawah ini menunjukkan hasil analisa komposisi biogas pada perbandingan komposisi 1:11,5 yang dilakukan di Laboratorium Pt Pertamina Ep, Region Sumatera Field Pangkalan Susu. Datanya sebagai berikut:

Tabel 2. Hasil Analisis Komposisi Biogas Limbah Kulit Buah Aren

\begin{tabular}{|l|c|}
\hline \multicolumn{2}{|c|}{ Komposisi Biogas } \\
\hline Metan $\left(\mathbf{C H}_{4}\right)$ & $60,9830 \%$ \\
\hline Karbondioksida $\left(\mathbf{C O}_{2}\right)$ & $35,2475 \%$ \\
\hline Nitrogen $\left(\mathbf{N}_{2}\right)$ & $3,6344 \%$ \\
\hline Gas Lain & $<1 \%$ \\
\hline
\end{tabular}

Berdasarkan penelitian yang telah dilakukan nyala api membuktikan berwarna biru pada semua variasi komposisi dan komposisi gas metan mencapai 60,9830\%. Metan $\left(\mathrm{CH}_{4}\right)$ adalah komponen penting dan utama dari biogas karena memiliki kadar kalor yang cukup tinggi dan jika gas yang dihasilkan dari proses fermentasi anaerob ini dapat terbakar, berarti sedikitnya mengandung 45\% metan [1]. Dimana biogas pada umumnya memiliki kandugan metan pada rentang 50-75\% [14]. Oleh karena itu, dapat dianggap bahwa biogas hasil penelitian ini layak untuk digunakan dan teknologi produksinya dapat dikembangkan lebih lanjut.

\section{Kesimpulan}

Hasil penelitian ini memberikan kesimpulan sebagai berikut :

1. Volume biogas optimum pada hari ke-18 pada semua variasi komposisi.

2. Volume biogas terbesar diperoleh pada perbandingan komposisi limbah padat (kulit buah aren) dan air 1:11,5 yaitu $637 \mathrm{ml}$.

3. Penyisihan Total Suspended Solid (TSS) terbesar diperoleh pada hari ke-27 pada perbandingan berat limbah padat (kulit buah aren) dan air 1:9 dengan nilai $94,61 \%$.

4. Penyisihan Chemical Oxygen Demand (COD) terbesar diperoleh pada hari ke-27 pada perbandingan berat limbah padat (kulit buah aren) dan air 1:11,5 dengan nilai 82,43\%.

5. Nilai $\mathrm{pH}$ awal untuk semua perbandingan adalah 7, dan pada prosesnya untuk semua perbandingan range perubahan $\mathrm{pH}$ berkisar antara 5-7.

6. Hasil analisa uji nyala biogas pada setiap variasi menunjukan nyala api biru dengan komposisi gas metan sebesar 60,9830\%.
7. Yield biogas yang dihasilkan dari fermentasi limbah kulit buah aren yaitu sebesar 189,8 ml/gr COD terkonversi. Sehingga limbah kulit buah aren berpotensi untuk dijadikan sebagai bahan baku pembuatan biogas.

\section{Daftar Pustaka}

[1] Agustina, Fransiska, Aplikasi Parameter Produk Biogas Dari Limbah Cair Industri Tapioka Dalam Bioreaktor Anaerobik 2 Tahap, Tesis, Teknik Kimia, Universitas Diponegoro, Semarang, 2011.

[2] A.V. Buren, A Chinese Biogas Manual, Intermediate Technology Publications Ltd., 1979.

[3] B. T. Bocher and M. T. Agler, Anaerobic Digestion Of Secondary Residuals From An Anaerobic Bioreactor At A Brewery To Enhance Bioenergy Generation, J Ind Microbiol Biotechnol, 2008.

[4] Dieter Deublein and Angelika Steinhauser, Biogas From Waste and Renewable Resources, An Introduction, Weinhem: Wiley-VCH Verlag GmbH \& Co, 2008.

[5] Eduardo Heyko, Strategi Pengembangan Energi Terbarukan : Studi Pada Biodiesel, Biethanol, Biomassa, dan Biogas di Indonesia, Jurnal Teknik Kimia, Universitas Brawijaya, Vol 4 (3), 2013.

[6] Imam Md, Forhad Ibne, M.Z.H. Khan, M.A.R. Sarkar, S.M. Ali, Development of Biogas Processing from Cow Dung, Poultry Waste, and Water Hyacinth, International Journal of Natural and Applied Science, 2 (1) 2013, hal. 13-17.

[7] Jorgensen, Peter Jacob, Biogas - Green Energy, Faculty of Agricultural Sciences, Aarhus University, 2nd edition, MIDT, 2009.

[8] Lasut, Marthen Theogives, Budidaya Yang Baik Aren (Arenga pinnata (Wurmb) Merr.), Fakultas Pertanian, Universitas Sam Ratulangi dan Univeristas Texas, A\&M, 2012.

[9] Lettinga Gatze and Haandel A.C.V, Anaerobic Sewage Treatment : A Practical Guide for Regions With A Hot Climate, John wiley and Son. Inggris, 1994.

[10] Milono P, T. Lindajati, and S. Aman. Biogas Production from Agricultural Organic Residues, The First ASEAN SeminarWorkshop on Biogas Technology, Working Group on Food waste Materials, 1981.

[11] Mu Sui, Arenga Pinnata (Wumb) Merr, Philiphine Medicinal Plants, Stuart X change, Pulang Lupa Foundation Inc, 2013.

[12] Mulyani, Sasongko, dan Soetrisnanto. Pengaruh Preklorinasi Terhadap Proses Start Up Pengolahan Limbah Cair Tapioka Sistem Anaerobic Baffled Reactor, Magister Teknik 
Kimia, Universitas Diponegoro, Semarang, Vol. 8, No. 1, 2012, hal 21- 27.

[13] Peraturan Menteri Pertanian Republik Indonesia, Pedoman Budidaya Aren (Arenga pinnata merr) yang Baik, No. 17, 2014, hal 4-28.

[14] Seadi Teodorita, et al., Biogas Handbook Denmark: Univeristy of Southern Denmark Esbjerg, 2008.

[15] Soemarno, Rancangan Teknologi Proses Pengolahan Tapioka dan Produk-Produknya. Magister Teknik Kimia, Universitas Brawijaya, Malang, 2007.

[16] Zalizar L., R. Relawati, dan B. Y. Ariadi, Potensi Produksi dan Ekonomi Biogas Serta Implikasinya Pada Kesehatan Manusia, Ternak, dan Lingkungan, Jurnal Ilmu - Ilmu Peternakan, Vol. 23 (3), 2013, hal $32-40$.
[17] Zamalloa, Carlos, Ellen Vulsteke, Johan Albrecht dan Wiley Verstraete, The Technoeconomic Potensial of Renewable Energy Through The Anaerobic Digestion Of Mikroalgae, Bioresource Technology, Vol. 102, 2011, hal $1149-1158$.

[18] Zuhdi, Ulwan , Bambang Dwi Argo, Musthofa Lutfi, dan M. Bagus Hermanto, Penyerapan Kandungan $\mathrm{CO}_{2}$ Biogas Dari Digester Tipe Fiz Dome Dan Digester Tipe Plastik Secara Kontinyu Dengan Mikroalga (Chlorella sp.), Jurnal Keteknikan Pertanian Tropis dan Biosistem, Vol. 2 (1), 2014, hal $33-41$. 